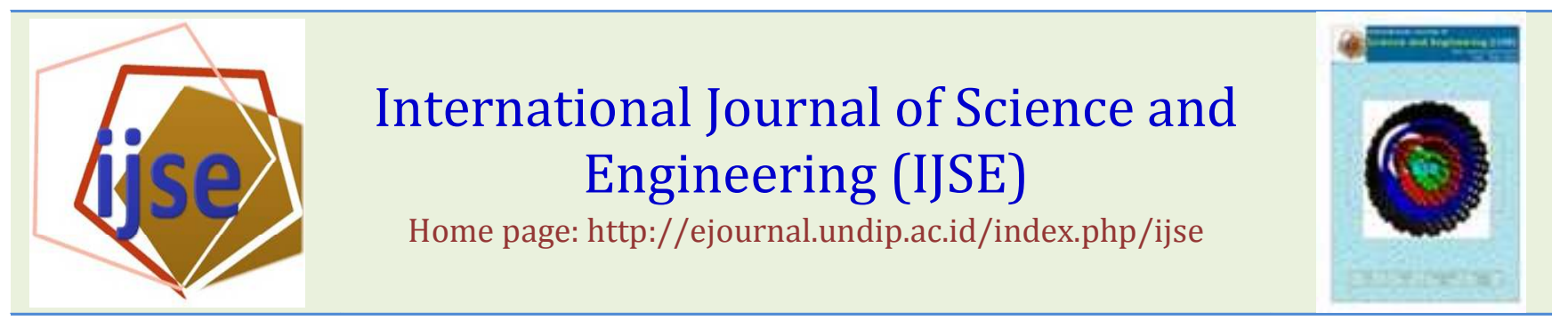

\title{
Growth performance and mineral status on goats (Caprahircuslinn.) supplemented with zinc proteinate and selenium yeast
}

\author{
${\text { Maharani Aditia1 }{ }^{1} \text { Sunarso }}^{1}$, C.C. Sevilla²andA.A. Angeles ${ }^{2}$ \\ ${ }^{1}$ Master program in Animal Science, Faculty of Animal Science and Agriculture, Diponegoro University, Semarang - \\ Indonesia \\ ${ }^{2}$ Animal Science and Dairy Cluster, University of the Philippine Los Baños - Philipine \\ Corresponding Author: Mahaditia@gmail.com
}

\begin{abstract}
The aim of this study was to determine the effects of dietary supplementation of Zn proteinate and Se yeast on growth performance and mineral status in local goats. Twenty two (22) doelings weighing $7.86 \pm 2.12 \mathrm{~kg}$ were grouped into 6 weight classes in a feeding trial to determine the effects of dietary zinc proteinate and selenium yeast on mineral status and growth performance. The $\mathrm{Zn}$-supplemented groups received $200 \mathrm{mg}$ additional $\mathrm{Zn}$ daily from chelated $\mathrm{Zn}$ proteinate, an insoluble powder containing 15\% elemental Zn. Se-supplemented groups received $3 \mathrm{mg}$ Se from Se yeast consisting mainly of selenomethionine (63\%). The four (4) dietary treatments were as follows: $T 1: 0 \mathrm{mg} \mathrm{Zn} \mathrm{+} 0 \mathrm{mg} \mathrm{Se}$; T2: $0 \mathrm{mg} \mathrm{Zn+3} \mathrm{mg} \mathrm{Se;} \mathrm{T3} \mathrm{:} 200 \mathrm{mg} \mathrm{Zn} \mathrm{+} 0 \mathrm{mg} \mathrm{Se}$. T4: $200 \mathrm{mg} \mathrm{Zn/head} \mathrm{+} 3$ $\mathrm{mg}$ Se/head. The experiment was conducted in a 2 × 2 factorial design in RCBD. Napier grass used in the trial contained 89.03 ppm Zn, while the mixture of corn-soybean oil meal had Zn content 49.73 ppm. Supplementation of Zn and Se in the diets composed of $60 \%$ Napier and 40\% soya-corn mix had no effect on dry matter intake, body weight gain, and feed efficiency. Giving $200 \mathrm{mg} \mathrm{Zn} / \mathrm{head}$ tends to increase $(\mathrm{P}<0.05)$ the $\mathrm{Zn}$ concentration in the blood of doelings among the levels of Se. Percent digestibility of Zn decreased with Zn supplementation at $200 \mathrm{mg}$. Percent apparent digestibility of $\mathrm{Zn}$ tends to be higher in animals without mineral supplementation. Results indicate that $\mathrm{Zn}$ and Se supplementation did not affect growth performance. Zn supplementation increased blood Zn concentration, but did not affect digestibility of Zn.
\end{abstract}

Key words- goats; minerals; digestibility; growth; performance

Submission: June 12, 2014

Corrected: July 30, 2014

Accepted: September 2, 2014

Doi: $10.12777 /$ ijse.7.2.124-129

[How to cite this article: Aditia, M., Sunarso., C.C. Sevilla, and A.A. Angeles (2014). Growth Performance and MineralStatus on Goats (Caprahircuslinn.)Supplemented with ZincProteinateandSeleniumYeast.International Journal of Science and Engineering, 7(2),124-129; Doi: $10.12777 /$ ijse.7.2.124-129

\section{Introduction}

In order to increase the animal productivity, people are trying to develop new technology to manipulate feed formulation such as silage, amofer technology, fermentation and ammonization to improve feed quality $[1 ; 2 ; 3 ; 4]$. Nutrient manipulation such protein-energy ratio was studied related to feed quality [5]. Among those technology regarding feed quality, farmer tend to be underestimate the availability of mineral among the available nutrients in the feed, since the needs of the animals are in small amount.Mineral nutrition of ruminant is a chronic problem since most forage plants contain varying levels of micro-minerals. To maintain the balance of minerals, the animals are given mixture of minerals to prevent deficiency that can cause certain diseases and maintain optimum productivity [6]. Underwood and Suttle[7] stated that minerals have the functions of the body's metabolic processes, among these are: structure, physiological, catalysts and regulator. Mineral requirements of goats are not fully understood or investigated, and established requirements are extrapolated largely from information from cattle and sheep [8].

$\mathrm{Zn}$ and Se are critical trace minerals for production and reproduction in farm animals. These minerals are absorbed and used to enhance performance, improve immunity, health and reproduction. While Se initially has been known as toxic element to some plants and animals, it is now recognized as one of the elements needed by the animal for growth and fertility[9]. The primary function of Se is in the synthesis of glutathione peroxsidose that helps deactivate oxygen radicals such hydrogen peroxide and prevents them from causing cellular damage [10]. Zn contributes to the growth and division of cells, antioxidants, sexual development, immune cell, dark adaptation, taste, and appetite [11]. 
Zinc is actively involved in enzyme function, most notably in metalloenzymes. The use of $\mathrm{Zn}$ as a supplementation is widely used in dairy cattle, in order to observe the effect of supplementation on milk quality parameters such as milk production, milk fat, milk protein and somatic cell count as well as studies conducted by Stanton et al.[12], Uchida et al. [13], Griffiths et al.[14].

For a long time, goat mineral nutrition has been considered as halfway between those of cattle and sheep [15]. There is limited research information about trace mineral in goats compared with other ruminants such sheep and cattle [16], hence, this study. Therefore, objectives of this study were to determine the effects of dietary supplementation of Zn proteinate and Se yeast on growth performance and mineral status in local goats.

\section{Materials and Methods}

\section{A. Animals and Experimental Design}

Twenty-two (22) 5-7 month old female goats or doelings were used. The body weight ranged from 5 to $10 \mathrm{~kg}$ with an average body weight of $7.86 \pm 2.12 \mathrm{~kg}(\mathrm{CV}$ $=26.81 \%$ ). The doelings were blocked by body weight and randomly assigned in to 4 dietary treatments. Prior to the start of the experiment, the doelingswere treated with antiparasitic, anthelmintic and antibiotic to control external and internal parasite. Likewise, the animals were also injected with vitamin A, D and E. Animals were maintained under uniform management condition. The housing was well ventilated with adequate facilities for individual feeding. Animals were allowed one week adjusment period and 1 week preliminary stage.

Table 1. Dietary composition of the basal diet (\%) and its chemical composition

\begin{tabular}{|l|c|c|}
\hline Ingredient & \multicolumn{2}{|c|}{ Composition (\%)* } \\
\hline Napier & \multicolumn{2}{|c|}{60} \\
\hline Soybean oil meal & \multicolumn{2}{|c|}{55} \\
\hline Yellow corn & \multicolumn{2}{|c|}{} \\
\hline $\begin{array}{l}\text { Chemical } \\
\text { composition }\end{array}$ & Concentrate feed 1 & $\begin{array}{c}\text { Napier } \\
\text { grass }^{1}\end{array}$ \\
\hline Organic matter & 94.96 & 82.27 \\
\hline Crude protein & 15.31 & 14.78 \\
\hline Ash & 5.04 & 17.73 \\
\hline Energy $($ Kcal $/ \mathrm{kg})$ & 4230 & 3762 \\
\hline $\mathrm{Zn}(\mathrm{ppm})$ & 49.73 & 89.03 \\
\hline Se $(\mu / \mathrm{kg})$ & & $17.80^{3}$ \\
\hline
\end{tabular}

* Based on dry matter basis

1 Reported result from Animal Nutrition Laboratory; Animaland Dairy Science Cluster, UPLB

${ }^{2}$ Reported result from Chemistry Science Laboratory; UPLB

${ }^{3}$ Reported result from Fujiharaet al., 1992

The feed was composed of corn and soy bean oil meal (SBOM) (Table 1), while Napier grass was the source of roughage. The diet was given at roughage:concentrate ratio at 60:40 based on DM requirement. The diet was formulated to be adequate in protein and energy for the class of goats. The doelings were fed in the morning at 8:00 and 14:00 hours. Ad libitum access to water was maintained throughout the study. Doelings were fed individually to meet the nutrient requirements of animals for maintenance and growth at $4.4 \%$ of body weight based on dry matter basis [17] for 84 days.

$\mathrm{Zn}$ proteinate and Se yeast/methionine were added to the concentrate. $\mathrm{Zn}$ proteinate was added at $0 \mathrm{mg}$ and $200 \mathrm{mg} /$ day/head, while Se at $0 \mathrm{mg}$ and $3 \mathrm{mg} /$ day/head. A 2 × 2 factorial design was used, where Factor 1 was $\mathrm{Zn}$ (with $\mathrm{Zn}$ and without $\mathrm{Zn}$ ) and Factor 2 was Se (with Se and without Se). Treatment combinantions were as follows: T1 : Without $\mathrm{Zn}$ and Se; T2 : With Se and without Zn; T3 : With Zn and without Se; and T4 : With Zn and Se. The Zn-supplemented groups received $200 \mathrm{mg}$ additional $\mathrm{Zn}$ daily from chelated $\mathrm{Zn}$ proteinate (Alltech), which is an insoluble powder containing $15 \%$ elemental $\mathrm{Zn}$. Se-supplemented groups received $3 \mathrm{mg}$ additional Se from Se yeast which contains $97-99 \%$ organic Se consisting mainly of selenomethionine $(63 \%)$ and low molecular weight selenocomponent (34-36\%).

\section{B. Data Collection}

The concentrate mixture and Napier grass were analyzed for proximate components and also for $\mathrm{Zn}$ and Se contents.

\section{Feeding trial}

The doelings were weighed at day 0 to obtain the initial body weight. Feed offered was recorded daily for each animal and feed refusal was weighed the next morning before feeding to calculate the feed intake. Feeding trial lasted for 84 days. The dry matter intake was calculated by substracting the total weight of feed refused multiplied by percent of dry matter from the total of feed offered multiplied by percent of dry matter of feed. During the feeding period, the animals were weighed every 2 weeks and the amount of feed offered was adjusted after each weighing. At the end of the experiment, the final body weight of the doelings was taken. Data on live weight gain, feed intake, and feed efficieny were gathered.

\section{Mineral Blood Concentration}

Blood samples were collected twice, at day 0 of the experiment and then at day 77 of the experimental period. The collection of $10 \mathrm{ml}$ whole blood was via jugular venipuncture using stainless steel needles. The collected blood samples were placed into $50 \mathrm{ml}$ crucible. The crucibles were immediately transported to the laboratory for weight determination followed by oven drying $70^{\circ} \mathrm{C}$ for 2 days. Dry matter content was determined by drying the blood in to oven $105^{\circ} \mathrm{C}$ overnight and ashed at a furnace temperature of $550^{\circ} \mathrm{C}$. Subsequently, the blood ash was dissolved in $\mathrm{HCl}(1+3)$ and 5 drops of $\mathrm{HNO}_{3}$ and evaporated to about $5 \mathrm{ml}$, and diluted to $50 \mathrm{ml}$ volumetric flash with distilled water then filtered before reading for $\mathrm{Zn}$ and Se contents using atomic absorption spectrophotometry (AAS) and inductively coupled plasma (ICP), repectively.

\section{E. Statistical Analysis}

The data collected were analyzed using analysis of variance (ANOVA) with $2 \times 2$ factorial in RCBD according to Gomez and Gomez [18]. Treatment mean differences were organized by Tukey's test with error level $(\alpha)$ 5\% using MINITAB 14. 


\section{Results and Discussions \\ Diet Composition}

cereal grains and other seeds tend to be lower than in the grass depending on the location with values ranging from $0.006 \mathrm{mg} / \mathrm{kg}$ DM to $3 \mathrm{mg} / \mathrm{kg}$ DM [19]. The Zn and Se content of drinking water were negligible and hence, were not accounted in the calculation of $\mathrm{Zn}$ and Se ntake. The corn-SBOM mix diet contained 73.306 ppm of Zn.

\section{Feed Intake and Weight Gain}

As shown in Table 2, both levels of $\mathrm{Zn}$ and $\mathrm{Se}$ supplementation have no significant effects on the final body weight, body weight gain, average daily gain, dry matter intake and feed efficiency among the treatment, nor was there any interaction effects between $\mathrm{Zn}$ supplementation and Se supplementation.

Effects of Zn and Se supplementation on average daily protein intake (ADPI) were not significantly different. There were no interaction effects between $\mathrm{Zn}$ supplementation and Se supplementation. The mean of average daily protein intakes (ADPI) with 0 and $200 \mathrm{mg}$ of $\mathrm{Zn}$ proteinate were 51.24 and $55.63 \mathrm{~g}$, respectively, and 53.84 and $53.03 \mathrm{~g}$ with 0 and $3 \mathrm{mg}$ of Se.

The doelings supplemented with $\mathrm{Zn}$ proteinate and Se methionine did not show higher final body weight, faster average daily gain, higher feed intake and also better feed efficiency. A low level of feed efficiency was positively related to ADG, where the average growth of doelings were also very low. Nugorohoet al. [25], found the Philippines native goats has an average ADG of 13.92 $\mathrm{g} / \mathrm{d}$ which is higher than this study on treatment with 0 mg of $\mathrm{Zn}$ supplementation resulted $6.60 \mathrm{~g} /$ day and lower than this study with $200 \mathrm{mg}$ of $\mathrm{Zn}$ proteinate resulted $14.39 \mathrm{~g} / \mathrm{d}$. Similar observations were reported by Pal et al. [20] and Mandalet al. [26] where supplementation with organic source of $\mathrm{Cu}$ and $\mathrm{Zn}$ did not differ on final body weight, body weight gain, average daily gain, and feed efficiency. Other studies have shown that by supplementing $\mathrm{Zn}$ the ADG increases [27 and 28]. Compared with the marginal dietary level of 20-33 ppm $\mathrm{Zn}$ for goats as stated by NRC [23[, this level of $\mathrm{Zn}$ in present experiment was $30 \mathrm{ppm}$ of $\mathrm{Zn} \mathrm{(15 \%} \mathrm{of} 200 \mathrm{mg}$ of $\mathrm{Zn})$. The control diet in this experiment which contained 73.306 ppm of $\mathrm{Zn}$ suggested that $\mathrm{Zn}$ concentration in the control diet was more than adequate, which could have minimized potential for responses in body weight change, average daily gain, feed intake and feed efficiency due to change in Zn status. Masters (1984) as cited by Puchalaet al.[28] stated that the effect of dietary Zn supplementation, regardless of form, depends on the animal's nutrient status, particularly of minerals and protein. Increasing the dietary $\mathrm{Zn}$ concentration might
Napier contained 89.03 ppm of Zn, while Zn content of corn-SBOM was 49.72 ppm (Table 1). The Se content in

increase some parameters on growth performance of animal, but it does not work on the dietary $\mathrm{CP}$ as the dietary $\mathrm{CP}$ level is held constant. Thus, the fixed dietary $\mathrm{CP}$ concentration in the present experiment may have masked effects of increasing dietary $\mathrm{Zn}$ may have on growth performance.

Animals with $200 \mathrm{mg}$ of $\mathrm{Zn}$ proteinate have the same amount of feed intake compared to animals with $0 \mathrm{mg}$ of $\mathrm{Zn}$. No differences were observed in $\mathrm{Zn}$ and Se supplementation on the doelings in feed intake and protein intake in this experiment. Feed intake in this expereiment was set at $4.4 \%$ of body weight. The feeding regime should have unlimited opportunities for full expression of dietary treatment effects on feed intake [28]. The result of this study supports the findings of Garget al.[29] that giving $200 \mathrm{mg} \mathrm{Zn} / \mathrm{kg}$ of diet in the form of organic ( $\mathrm{Zn}$ methionine) did not improve intake of dry matter, organic matter, crude protein, digestible $\mathrm{CP}$ and and nutrients digestibility, compared to the administration of inorganic $\mathrm{Zn}(\mathrm{ZnSO})$ in the same amount on the lamb for 150 days. In the study of Jiaet al.[27], digestibility of DM, crude protein (CP), neutral detergent fiber (NDF) and acid detergent fiber (ADF) did not differ among treatments. Performance reponses to Zn supplementation of ruminant diet have been variable. Some of the studies on $\mathrm{Zn}$ treatment have shown different responses although the animals received the same amount from different sources. From these findings, it can be said that the type of animal, breed, stage of growth, feed, and environmental conditions also greatly affect the absorption and metabolism of trace minerals in the body. It is suggested that the basal diet with $73.306 \mathrm{mg} \mathrm{Zn/kg} \mathrm{DM} \mathrm{can} \mathrm{support} \mathrm{normal} \mathrm{growth} \mathrm{in}$ the doelings, and supplementation above that level has no further impact.

\section{Blood Mineral Status}

\section{Zn Supplementation}

Final Zn concentrations in the doeling's blood were not significantly different between treatments. The levels of both factors had also the same average and did not increase the $\mathrm{Zn}$ concentration in the blood. There was no significant interaction effects between the factors.The final $\mathrm{Zn}$ concentrations in blood among the levels of $\mathrm{Zn}$ supplementations were the same, as well as for Se supplementations. Supplementing $\mathrm{Zn}$ of as much as 30 mg (15\% elemental $\mathrm{Zn}$ of $200 \mathrm{mg}$ ) could not increase $\mathrm{Zn}$ concentration in the blood, which is dietary $\mathrm{Zn}$ concentration (post treatment) held constant.

Table 2. Dry matter intake, protein intake, final body weight, body weight gain, average daily gain and feed efficiency ofdoelings supplemented with $\mathrm{Zn}$ and/or Se

\begin{tabular}{|c|c|c|c|c|c|c|c|c|}
\hline No. & Zn & Se & $\begin{array}{c}\text { DMI } \\
\text { (g/day) }\end{array}$ & $\begin{array}{l}\text { Protein } \\
\text { intake (g of } \\
\text { DM) }\end{array}$ & $\begin{array}{c}\text { Final } \\
\text { BW (kg) }\end{array}$ & $\begin{array}{l}\text { BWG } \\
(\mathrm{kg})\end{array}$ & $\begin{array}{c}\text { ADG } \\
\text { (g/day) }\end{array}$ & $\begin{array}{l}\text { Feedefficiency } \\
(\mathrm{kg} / \mathrm{kg})\end{array}$ \\
\hline 1 & \multirow{2}{*}{$0 \mathrm{mg}$} & $0 \mathrm{mg}$ & 334.57 & 50.12 & 8.52 & 0.43 & 5.16 & 1.59 \\
\hline 2 & & $3 \mathrm{mg}$ & 349.46 & 52.35 & 8.93 & 0.68 & 8.04 & 1.69 \\
\hline 3 & \multicolumn{2}{|c|}{ Mean } & 342.02 & 51.24 & 8.73 & 0.56 & 6.60 & 1.64 \\
\hline 4 & 200 & $0 \mathrm{mg}$ & 384.39 & 57.55 & 9.67 & 1.40 & 16.67 & 4.19 \\
\hline
\end{tabular}




\begin{tabular}{|c|c|c|c|c|c|c|c|c|}
\hline No. & Zn & Se & $\begin{array}{c}\text { DMI } \\
\text { (g/day) }\end{array}$ & $\begin{array}{c}\text { Protein } \\
\text { intake (g of } \\
\text { DM) }\end{array}$ & $\begin{array}{c}\text { Final } \\
\text { BW (kg) }\end{array}$ & $\begin{array}{c}\text { BWG } \\
(\mathrm{kg})\end{array}$ & $\begin{array}{c}\text { ADG } \\
\text { (g/day) }\end{array}$ & $\begin{array}{c}\text { Feedefficiency } \\
\text { (kg/kg) }\end{array}$ \\
\hline 5 & $\mathrm{mg}$ & $3 \mathrm{mg}$ & 358.62 & 53.70 & 8.68 & 1.02 & 12.10 & 3.13 \\
\hline 6 & \multicolumn{2}{|c|}{ Mean } & 371.51 & 55.63 & 9.18 & 1.21 & 14.39 & 3.66 \\
\hline
\end{tabular}

The mean blood change concentrations of $\mathrm{Zn}$ among $\mathrm{Zn}$ levels as well as the level of Se supplementation were significantly different $(\mathrm{P}<0.05)$. Still, there was no interaction effect between $\mathrm{Zn}$ supplementation and Se supplementation.

Table 3. Zn concentration in blood of doelings supplemented with $\mathrm{Zn}$ and/or Se

\begin{tabular}{|c|c|c|c|c|c|}
\hline No. & $\mathrm{Zn}$ & Se & $\begin{array}{c}\text { Initial Zn } \\
(\mathrm{ppm})\end{array}$ & $\begin{array}{c}\text { Final Zn } \\
(\mathrm{ppm})\end{array}$ & $\begin{array}{c}\text { Change } \\
\text { (ppm) }\end{array}$ \\
\hline 1 & \multirow{2}{*}{$0 \mathrm{mg}$} & $0 \mathrm{mg}$ & $2.20^{\mathrm{a}}$ & 2.88 & $0.67 \mathrm{~b}$ \\
\hline 2 & & $3 \mathrm{mg}$ & $3.48^{\mathrm{a}}$ & 1.92 & $-1.56^{a}$ \\
\hline 3 & \multicolumn{2}{|c|}{ Mean } & $2.84 y$ & 2.40 & $0.44 y$ \\
\hline 4 & \multirow{2}{*}{$\begin{array}{l}200 \\
\mathrm{mg}\end{array}$} & $0 \mathrm{mg}$ & $1.70^{\mathrm{a}}$ & 3.24 & $1.54 \mathrm{~b}$ \\
\hline 5 & & $3 \mathrm{mg}$ & $1.94^{\mathrm{a}}$ & 2.70 & $0.76^{\mathrm{a}}$ \\
\hline 6 & \multicolumn{2}{|c|}{ Mean } & $1.82^{\mathrm{x}}$ & 2.97 & $1.15^{\mathrm{x}}$ \\
\hline
\end{tabular}

Differentsuperscripts within columns denote significant differences $(\mathrm{P}<0.05)$

Supplementing $\mathrm{Zn}$ proteinate at $200 \mathrm{mg}$ level obviously increased $(\mathrm{P}<0.05)$ the total $\mathrm{Zn}$ intake by as much as $57.77 \mathrm{ppm}$ compared to $25.39 \mathrm{ppm}$ for $0 \mathrm{mg}$ of $\mathrm{Zn}$. However, the levels of Se supplementation have the same mean on $\mathrm{Zn}$ intake. The means of $\mathrm{Zn}$ intake with 0 and $3 \mathrm{mg}$ of Se supplementation were 41.8 and 41.36 ppm, respectively. There were no significant interactions between $\mathrm{Zn}$ and Se supplementation.

Supplementing $\mathrm{Zn}$ resulted in significant differences $(\mathrm{P}<0.05)$ on fecal $\mathrm{Zn}$ among the levels. On the other hand, supplementing Se resulted in the same mean on $\mathrm{Zn}$ feces among the levels and there were no interaction effects between $\mathrm{Zn}$ supplementation and Se supplementation.

$\mathrm{Zn}$ digestibility of diets supplemented with $\mathrm{Zn}$ had different means $(\mathrm{P}<0.05)$. Supplementing Se, however, had the same mean on $\mathrm{Zn}$ digestibility among the levels as there were no interactions between $\mathrm{Zn}$ and $\mathrm{Se}$ supplementation.

Table 4. Total Zn intake, fecal Zn, apparent Zn digestibility ofdoelings supplemented with $\mathrm{Zn}$ and/or Se

\begin{tabular}{|c|c|c|c|c|c|c|}
\hline No. & $\mathrm{Zn}$ & $\mathrm{Se}$ & $\begin{array}{l}\text { Total } \\
\text { Zn } \\
\text { intake } \\
(\mathrm{mg})\end{array}$ & $\begin{array}{c}\mathrm{Zn} \\
\text { feces } \\
(\mathrm{mg})\end{array}$ & $\begin{array}{c}\mathrm{Zn} \\
\text { digested } \\
\text { (mg) }\end{array}$ & $\begin{array}{c}\mathrm{Zn} \\
\text { digestibility } \\
(\%)\end{array}$ \\
\hline 1 & 0 & $0 \mathrm{mg}$ & $24.84^{a}$ & $3.56^{\mathrm{a}}$ & 21.28 & $85.22^{\mathrm{a}}$ \\
\hline 2 & $\mathrm{mg}$ & $3 \mathrm{mg}$ & $25.95^{\mathrm{a}}$ & $2.64^{\mathrm{a}}$ & 23.31 & $89.82^{\mathrm{a}}$ \\
\hline 3 & \multicolumn{2}{|c|}{ Mean } & $25.39 y$ & $3.10^{\mathrm{y}}$ & 22.30 & $87.52^{y}$ \\
\hline 4 & \multirow{2}{*}{$\begin{array}{c}200 \\
\mathrm{mg}\end{array}$} & $0 \mathrm{mg}$ & $58.76^{a}$ & $37.17^{a}$ & 21.60 & $38.16^{\mathrm{a}}$ \\
\hline 5 & & $3 \mathrm{mg}$ & $56.77^{a}$ & $35.51^{a}$ & 21.26 & $37.97 \mathrm{a}$ \\
\hline 6 & \multicolumn{2}{|c|}{ Mean } & $57.77 \mathrm{x}$ & $36.34^{x}$ & 21.43 & $38.06^{x}$ \\
\hline
\end{tabular}

Different superscripts within columns denote significant differences $(\mathrm{P}<0.05)$

The diet in the present experiment contained 73.30 ppm Zn. Overall, it appears that Zn content in the control diet in the present experiment was adequate. Several studies showed significant increased in plasma $\mathrm{Zn}$ concentration as effect of $\mathrm{Zn}$ supplementation. In the study of Jiaet al. [27], plasma $\mathrm{Zn}$ concentrations increased $(\mathrm{P}<0.01)$ with $\mathrm{Zn}$ supplementation and were higher $(\mathrm{P}<0.05)$ for the treatment groups supplemented with 30 and $45 \mathrm{mg} \mathrm{Zn} / \mathrm{kg}$ DM. The study of Puchalaet al.[28] revealed that supplementation of the diet with Zn-methionine treatments (1, 3, and $5 \mathrm{mg}$ /day Zn-Met) increased $(\mathrm{P}<0: 03)$ plasma $\mathrm{Zn}$ concentration $(0.92$ versus $0.72 \mathrm{mg} / \mathrm{l}$ for control).

Plasma $\mathrm{Zn}$ and $\mathrm{Cu}$ concentrations were significantly higher $(\mathrm{P}<0.05)$ in ewes that consumed Cu-Met + Zn-Meth [20]. In contrast, Ryan et al.[30] did not find any difference in the plasma $\mathrm{Zn}$ concentration in adult sheep that were daily supplemented with 75 and $150 \mathrm{mg}$ of $\mathrm{Zn}$ either as Bioplex $\mathrm{Zn}$ (chelated $\mathrm{Zn}$ ) or inorganic $\mathrm{Zn}$ (ZnSO).

Zn content in the basal diet seemed to have been able to provide $\mathrm{Zn}$ to meet the requirement of the doelings. Animals fed with $200 \mathrm{mg}$ of $\mathrm{Zn}$ digested only small amounts as needed while the remainder was excreted through feces. These data are supported by the level of $\mathrm{Zn}$ content in the feces. Animals with $200 \mathrm{mg} \mathrm{Zn}$ supplementation showed high fecal $\mathrm{Zn}$, while animals without $\mathrm{Zn}$ supplementation ( $0 \mathrm{mg}$ ) resulted to small amount of $\mathrm{Zn}$ in the feces. Percentage of apparent digestibility showed contrasting results. Animals fed with $200 \mathrm{mg}$ of $\mathrm{Zn}$ showed less absorption, while animals without $\mathrm{Zn}$ supplementation had a higher digestibility. This indicates that animals utilize $\mathrm{Zn}$ received according to their requirements and the rest are excreted. Lonnerdal[31] said that by increasing the amount of $\mathrm{Zn}$ in a meal, fractional $\mathrm{Zn}$ absorption (\%) will decrease, whereas the amount of $\mathrm{Zn}$ absorbed increases linearly at higher dietary levels, which would be consistent with a diffusion process. This study strengthens the findings of Miller [32] that percentage absorption of $\mathrm{Zn}$ from feed materials will decrease with increasing dietary Zn on ruminant. The observed apparent $\mathrm{Zn}$ absorption values also confirm the findings of Reid et al.[33] that the percentage of absorbed $\mathrm{Zn}$ decreases with increasing dietary Zn level.

\section{Se Supplementation}

Se concentration in the blood was conducted prior to the experiment to get the initial $\mathrm{Zn}$ concentration and later after 77 days feeding period. Based on the analysis, Se concentration in blood, both at the initial and final phases, could not be detected because the concentration of Se was very low. Se contained in the blood, fecal, feed and also forage was not detected due to the low amount and could not reach the limit detection of the instruments (AAS and ICP). Both dry and wet ashing methods were used to digest the samples, sample size was also increased and yet could not be detected. Although several methods can be used for selenium determination, the volatility and instability of certain forms of selenium and the non-homogeneity of sample 
materials are the common challenges for all analytical procedures [19].

Low absorption of Se in ruminants is believed to result from reduction of dietary Se to insoluble forms such as elemental Se or selenides in the rumen environment [34]. Another factor that affects the absorption of Se is mineral antagonism. Association mineral with fibers in the feedstuff or mineral bond with undigested fiber constituents in the gastrointestinal tract may alter the bioavailability of some trace minerals in the ruminant. Rumen conditions with $\mathrm{pH}$ 6-6.8 produce a trace mineral that forms insoluble.

\section{Conclusions}

The supplementation of $\mathrm{Zn}$ and $\mathrm{Se}$ in the diets composed $60 \%$ forage and $40 \%$ corn-SBOM had no effect on BWG, ADG, feed efficiency, total intake of dry matter and also total intake of crude protein. Giving 200 $\mathrm{mg} / \mathrm{head}$ of $\mathrm{Zn}$ tends to increase the $\mathrm{Zn}$ concentration in the blood of doelings, but was not significantly diferrent among the level of Se. Based on the analysis, Napier has a fairly high content of $\mathrm{Zn}$. In addition, the mixture of SBOM-corn feed used has high Zn content. Zn content in the basal diet seems to be sufficient for the doelings. Because of the apparent digestibility of Zn treatment for almost all the same, hereinafter excess minerals are excreted in feces. Percent digestibility of $\mathrm{Zn}$ decreased with $\mathrm{Zn}$ supplementation of $200 \mathrm{mg} / \mathrm{head}$ and otherwise, percent of apparent digestibility of $\mathrm{Zn}$ to be higher in animals with $0 \mathrm{mg}$ of mineral supplementation.

$\mathrm{Zn}$ and Se supplementation showed increase in blood concentration of zinc, but not on growth performance. Selenium content in the forage, feed and blood in this study could not be detected by AAS and ICP. Both dry and wet ashing methods were used to digest the sample, and sample size was also increased. This was due to the small amount of selenium in the sample used.

\section{Acknowledgment}

The author gratefully appreciates the support received from the BeasiswaUnggulan BPKLN Indonesia, Dr. Cesar C. Sevilla, Director of ADSC - UPLB, Prof. Dr. Sumarsono MS - UNDIP, Dr. Ir. ParistiyantiNurwardani, MP, Education Attache of Indonesian Embassy in Manila and faculty staff of master program in Animal Science (MIT) UNDIP. In addition, the expert advise of the reviewers for the improvement of this manuscript is sincerely appreciated.

\section{References}

\section{[1] Sunarso.}

Pakanruminansiadalamsistemintegrasiternak-pertanian

(Pidatopengukuhan Guru BesarUniversitasDiponegorotanggal 10 September 2003). BadanPenerbitUniversitasDiponegoro Semarang.

[2] Sunarso. 2013. The effect of king grass silage on the nitrogen balance and hematological profile of Ettawa grade male goat. Internat. J. of Sci. and Eng. 3 (1):13-16.

[3] Mayulu, H., S. Sunarso, C. Imam Sutrisno and Sumarsono. 2012. The effects of amofer palm oil waste-based complete feed to blood profiles and liver function on local sheep. Internat. J. of Sci. and Eng. 3(1):17-21

[4] Mayulu, H., Sunarso, S., Christiyanto, M. and Ballo, F. 2013. Intake and digestibility of cattle's ration on complete feed based-on fermented ammonization rice straw with different protein level. Internat. J. of Sci. and Eng.4(2):86-91.
[5] Mawati, S., S. Soedarsono, S. Sunarso and A. Purnomoadi. (2013). The effects of different energy and ratio to sheep's nutrient intake and digestibility. Internat. J. of Sci. and Eng.4(2):76-79.

[6] Solaiman, S.G., C.E. Shoemaker, G.H. D'andrea. 2006. The effect of high dietary $\mathrm{Cu}$ on health, growth performance, and $\mathrm{Cu}$ status in young goats. Small Rum. Res. 66:85-91.

[7] Underwood, E.J. and N. F. Suttle.1999. The MineralNutrition of Livestock. CABI Publishing. New York, USA.

[8] Solaiman, S. G. 2010. Goat Science and Production. Blackwell Publishing. USA.

[9] Engle, T.E. 2007. The Role of Trace Minerals in Immunity and LipidMetabolism in Cattle. Animal Science Dept. of Colorado State University.

[10] National Research Council (NRC). 2005. Mineral Tolerance of Animal. National Academies Press. USA.

[11] Solomon, N.W. 1993. Zinc encyclopedia of food science, food technology and nutrition. Vol 7. London. $49: 80-94$

[12] Stanton, T. L., J.C. Whittier, T.W. Geary, C.V. Kimberling and A.B. Johnson. 2000. Effects of trace mineral supplementation on cow-calf performance, reproduction, and immune function. Prof. Anim. Sci. 16:121-127.

[13] Uchida. K., P. Mandebvu, C.S. Ballard, C.J. Sniffen and M.P Carter. 2001. Effect of feeding combination of $\mathrm{Zn}$, manganese, copper amino acid complexes, and cobalt glucoheptonate on performance of early lactation high producing dairy cattle. Anim. Feed Sci. and Tech. 93:193-203

[14] Griffiths, L.M., S.H. Loeffler, M.T. Socha, D.J. Tomlinson and A.B. Johnson. 2007. Effects of supplementing complexed zinc, manganese, copper and cobalt on lactation and reproductive performance of intensively grazed lactating dairy cattle on the south island of New Zealand. Anim. Feed Sci. and Tech. 137:69-83

[15] Meschy, F. 2000. Recent progress in the assesment of mineral requirements of goats. Livestock Prod. Sci. 64 : 9-14.

[16] Haenlein, G. F.W. and M. Anke. 2011. Mineral and trace element research in goats: a review. Small Rum. Res. $95: 2-19$.

[17] Kearl, L.C. 1982. Nutrient Requirements of Ruminants in DevelopingCountries. Internationals Feedstuff Institute. Utah Agric Exp. Station. Utah State University Logan Utah, 84332, USA.

[18] Gomez, K.A. and A.A. Gomez. 1984. Statistical Procedures for AgriculturalResearch. 2nd Ed. John Wiley \& Sons, Inc. New York.

[19] National Research Council (NRC). 1983. Underutilized Resources as AnimalFeedstufs. National Academies Press. USA.

[20] Pal, D.T., N.K.S. Gowda, C.S. Prasad, R. Amarnath, U. Bharadwaj, G. Sureshbabu and K.T. Sampath. 2010. Effect of copper- and zinc-methionine supplementation on bioavailability, mineral status and tissue concentrations of copper and $\mathrm{Zn}$ in ewes. J. of Trace Elements in Medicine and Biology. 24:89-94.

[21] Arthington, J. D. and F.M. Pate. 2002. Effect of corn- vs molasses-based supplements on trace mineral status in beef heifers. J. Anim. Sci. 80 :2787-2791.

[22] Minson, D. J. 1990. Forage in RuminantNutrition. Academic Press, Inc,. San Diego, USA.

[23] National Research Council (NRC). 1981. Nutrient Requirements of Goats. National Academies Press. USA.

[24] National Research Council (NRC). 2007. Nutrient Requirements of Small Ruminants. National Academies Press. USA.

[25] Nugroho, D., S. Sunarso, C.S. Sevilla and A.A. Angeles. (2014). The Effects of dietary neutral detergent fiber ratio from forage and concentrate on the dietary rumen degradability and growth performance of Philippine native goats (Capra hircus Linn.). Internat. J. of Sci. and Eng. 6 (1):75-80.

[26] Mandal, G. P., R.S. Dass, D.P. Isore, A.K. Garg and G.C. Ram. (2007). Effect of Zn supplementation from two sources on growth, nutrient utilization and immune response in male crossbred cattle (bosIndicus x bosTaurus) bulls. Anim. Feed Sci and Tech. 138 (1) : 1-12.

[27] Jia, W. B., Z. H. Jia, W. Zhang, R. L. Wang, S. W. Zhang and X. P. Zhu. 2008. Effects of dietary zinc on performance, nutrient digestibility and plasma zinc status in Cashmere goats. Small Rum. Res. 80:68-72.

[28] Puchala, R., T. Sahlu and J.J. Davis. 1999. Effects of Zn-methionine on performance of Angora goats. Small. Rum. Res. 33 : 1-8.

[29] Garg, A.K., V. Mugdal and R.S. Dass. 2008. Effect of organic zinc supplementation on growth, nutrient utilization and mineral profile in lambs. Anim Feed Sci. and Tech. 144: 82-96.

[30] Ryan, J.P., P. Kearns, and T. Quinn. 2002. Bioavailability of dietary copper and zn in adult texel sheep: a comparative study of the effects of sulfate and bioplex supplementation. Irish Vet. J. 55 : 221-224. 
[31] Lőnnerdal, B. 2000. Dietary factors influencing zinc absorption American Society for Nutritional Sci. 130: 1378S-1383S.

[32] Miller, W. J. (1970). Zn nutrition of cattle : a review. J Dairy Sci. $53: 1123-1135$
[33] Reid, R.L., G.A. Jung, W.L. Stout, Ranney, and S. Teal, 1987. Effect of varying $\mathrm{Zn}$ concentrations on quality of alfalfa for lambs. J. Anim. Sci. 64 : 1735-1742.

[34] Spears, J.W. 2003. Trace mineral bioavailability in ruminants. J. Nutr. 133: 1506S-1509S. 